\title{
Article
}

Mycosphere

\section{Porodaedalea chinensis (Hymenochaetaceae, Basidiomycota) - a new polypore from China}

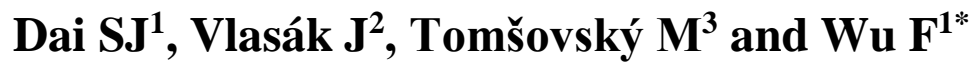 \\ ${ }^{1}$ Institute of Microbiology, PO Box 61, Beijing Forestry University, Beijing 100083, China \\ ${ }^{2}$ Biology Centre of the Academy of Sciences of the Czech Republic, Branišovská 31, CZ-37005, České Budějovice, \\ Czech Republic \\ ${ }^{3}$ Faculty of Forestry and Wood Technology, Mendel University in Brno, Zemédělská 3, CZ-61300, Czech Republic
}

Dai SJ, Vlasák J, Tomšovský M, Wu F 2017 - Porodaedalea chinensis (Hymenochaetaceae, Basidiomycota) - a new polypore from China. Mycosphere 8(6), 986-993, Doi 10.5943/mycosphere/8/6/2

\begin{abstract}
Porodaedalea chinensis is described and illustrated as a new species occurring on Pinus yunnanensis from southwestern China based on morphological and molecular characters. Phylogenetic analyses of the combined internal transcribed spacer (ITS) of ribosomal RNA gene and translation elongation factor 1-alpha $($ tefl- $\alpha$ ) sequences show that the new species forms a distinct lineage separating it from other Porodaedalea species. P. chinensis is characterized by perennial, pileate basidiocarps, relatively small pores (2-3 per $\mathrm{mm}$ ), a dimitic hyphal system with generative hyphae bearing simple septa which are frequent in trama and skeletal hyphae dominant in context and trama, broadly ellipsoid, hyaline, thin-to slightly thick-walled, smooth, moderately cyanophilous basidiospores measured as $4-6 \times 3-4.8 \mu \mathrm{m}$, and having a distribution in southwestern China.
\end{abstract}

Key words - Hymenochaetales - phylogeny - taxonomy - wood-inhabiting fungi

\section{Introduction}

Porodaedalea Murrill, typified by Porodaedalea pini (Brot.) Murrill, is characterized by perennial, effused-reflexed to pileate basidiocarps, a dimitic hyphal structure with simple septa on generative hyphae, ventricose to subulate hymenial setae originating from subhymenim, and subglobose, broadly ellipsoid to ovoid, slightly to fairly thick-walled, moderately cyanophilous basidiospores (Murrill 1905, Dai 2010, Tomšovský et al. 2010). All species of the genus grow on gymnosperm wood and cause a white pocket rot.

A basic outline for Porodaedalea was established by Fiasson \& Niemelä (1984) based on morphological and biochemical features. Wagner \& Fischer (2002) confirmed Porodaedalea as an independent genus through the nuclear large subunit (nLSU) ribosomal RNA-based phylogeny. In Europe, Porodaedalea pini, P. chrysoloma (Fr.) Fiasson \& Niemelä and P. laricis (Jacz. ex Pilát) Niemelä are well known and have a wide distribution (Niemelä et al. 2005, Tomšovský et al. 2010, Ryvarden \& Melo 2014). Another species, P. niemelaei M. Fischer growing on Larix from Finland was described by Fischer (2000), but the name was considered as a synonym of $P$. laricis by Niemelä et al. (2005). 
Based on morphology, Phellinus chrysoloma (Fr.) Donk, P. pini (Brot.) Bondartsev \& Singer and P. piceina (Peck) Pat. were recognized in North America (Niemelä 1985, Gilbertson \& Ryvarden 1987), then Porodaedalea cancriformans (M.J. Larsen, Lombard \& Aho) T. Wagner \& M. Fischer was described in northwestern North America by Wagner \& Fischer (2002).

In addition, based on the mating tests, Fischer (1994) reported seven unique taxa of Porodaedalea in North America: P. piceina (Peck) Niemelä (group 1) and six taxa as Porodaedalea group 2, 3, 4, 5, 6 and 7. Larsen (2000) described Porodaedalea group 3 as $P$. gilbertsonii M.J. Larsen. Based on inter-sterility tests and PCR-RFLP, Fischer (1996) indicated that inter-sterility group 4 was identical with group 6 and 7, and inter-sterility group 5 was identical with a northern Asian taxon. Brazee \& Lindner (2013) performed a multilocus phylogenetic analysis, which confirmed that a group labeled the 'Holarctic group' from Larix, Picea, Pinus, Pseudotsuga and Tsuga is distributed in North America, and that P. pini s.s. and P. chrysoloma s.s. do not occur in North America. Similar conclusions were published by Fischer (1994, 1996), Larsen \& Melo (1996), Larsen \& Stenlid (1999) and Larsen (2000). Recently only P. piceina and P. cancriformans were listed in North American polypores (Zhou et al. 2016).

Five species of Porodaedalea, P. chrysoloma, P. himalayensis (Y.C. Dai) Y.C. Dai, P. laricis, P. pini and P. yamanoi (Imazeki) Y.C. Dai, were recorded in East Asia (Dai 2010). Nevertheless, these species are poorly supported due to the lack of molecular data.

Recently, Porodaedalea cedrina Pilát ex Tomsovsky \& Kout occurring on Cedrus atlantica and C. libani was described from North Africa and Western Asia by phylogenetic analyses of the ITS rDNA region (internal transcribed spacer ribosomal DNA) and tefl- $\alpha$ (translation elongation factor 1- $\alpha$ ) genes (Tomšovský \& Kout 2013).

During investigations on poroid wood-inhabiting fungi on gymnosperms in China, one undescribed species belonging to Porodaedalea occurring on the living tree of Pinus yunnanensis was found in Yunnan Province, southwestern China. To confirm the affinity of these collections, phylogenetic analyses were carried out based on ITS and tefl- $\alpha$ sequences.

\section{Materials \& Methods}

\section{Morphological studies}

The studied specimens are deposited at the herbaria of the Institute of Microbiology, Beijing Forestry University (BJFC), National Museum Prague of Czech Republic (PRM), and the private herbarium of J. Vlasák (JV), and microscopic procedures followed He \& Li (2011) and Zhao et al. (2015). Microscopic features were described from dried materials prepared with cotton blue (CB), $5 \%$ potassium hydroxide $(\mathrm{KOH})$, and Melzer's reagent (IKI). Sections were studied at magnifications up to $1000 \times$ using a Nikon Eclipse 80i microscope with phase contrast illumination. At least 30 basidiospores and hymenial setae were measured each specimen, in presenting spores size data, 5\% of the measurements were excluded from each end of the range, and shown in parentheses. The following abbreviations were used: IKI $=$ Melzer's reagent, IKI $-=$ negative in Melzer's reagent, $\mathrm{KOH}=5 \%$ potassium hydroxide, $\mathrm{CB}=$ Cotton Blue, $\mathrm{CB}+=$ cyanophilous, $\mathrm{L}=$ mean spore length (arithmetic average of all spores), $\mathrm{W}=$ mean spore width (arithmetic average of all spores), $\mathrm{Q}=$ variation in the $\mathrm{L} / \mathrm{W}$ ratios, and $\mathrm{n}=$ number of spores measured from given number of specimens. Drawings were made with a drawing tube. Color terms followed Petersen (1996).

\section{Molecular study}

DNA was extracted from dried fruiting bodies. The DNA loci including the ITS and tefl- $\alpha$ were selected for the analysis, primer pair ITS5/ITS4 and 1487F/2218R were used, respectively (White et al. 1990, Rehner et al. 2005). The PCR reaction of ITS was performed as follows: initial denaturation at $95^{\circ} \mathrm{C}$ for 3 minutes, followed by 35 cycles at $94^{\circ} \mathrm{C}$ for 40 seconds, $54^{\circ} \mathrm{C}$ for 45 seconds and $72^{\circ} \mathrm{C}$ for 1 minute, and a final extension of $72^{\circ} \mathrm{C}$ for 10 minutes. For the amplification of tefl- $\alpha$, the PCR protocol was using a following touchdown regime: initiated with a 2 minutes 
denaturation at $94^{\circ} \mathrm{C}$. The annealing temperature in the first amplification cycle was $60^{\circ} \mathrm{C}$, which was subsequently incrementally reduced by $1^{\circ} \mathrm{C}$ per cycle over the next 9 cycles. An additional 35 amplification cycles were then performed, each consisting of 45 seconds denaturation at $94^{\circ} \mathrm{C}$, a 90 seconds annealing step at $53^{\circ} \mathrm{C}$, and a 2 minutes extension at $72^{\circ} \mathrm{C}$, concluding with a 10 minutes incubation at $72^{\circ} \mathrm{C}$. All newly generated sequences were deposited in GenBank database (Table 1).

Table 1 A list of species, vouchers and GenBank accession number of sequences used in this study.

\begin{tabular}{|c|c|c|c|c|c|}
\hline \multirow[t]{2}{*}{ Species } & \multirow[t]{2}{*}{ Sample no. } & \multirow[t]{2}{*}{ Locality } & \multirow{2}{*}{ Substrate } & \multicolumn{2}{|c|}{ GenBank accession no. } \\
\hline & & & & ITS & tef1- $\alpha$ \\
\hline $\begin{array}{l}\text { Porodaedalea } \\
\text { cedrina }\end{array}$ & JK 0908/04-3 & $\begin{array}{l}\text { Morocco, Middle } \\
\text { Atlas }\end{array}$ & Cedrus atlantica & JQ772468 & JQ772474 \\
\hline P. cedrina & MCF 03/1167 & $\begin{array}{l}\text { Turkey, Fethiye- } \\
\text { Babadağ Mt. }\end{array}$ & Cedrus libani & JQ772467 & JQ772473 \\
\hline P. chrysoloma & BRNM 712790 & Sweden, Uppsala & Picea abies & FJ775543 & FJ775576 \\
\hline P. chrysoloma & BRNM 712788 & $\begin{array}{l}\text { Czech, Moravian } \\
\text { Karst }\end{array}$ & Picea abies & FJ775547 & FJ775577 \\
\hline P. chrysoloma & Dai 12674 (BJFC) & Finland, Helsinki & Picea abies & KY000004a & KY000009a \\
\hline P. chrysoloma & JV 1408/40-J & Czech, Hrensko & Picea abies & KY000006a & KY000011a \\
\hline P. chinensis & Cui 10252 (BJFC) & $\begin{array}{l}\text { China, Yunnan } \\
\text { Province }\end{array}$ & Pinus yunnanensis & KX673606a & KX852283a \\
\hline P. chinensis & Dai 16864 (BJFC) & $\begin{array}{l}\text { China, Yunnan } \\
\text { Province }\end{array}$ & Pinus yunnanensis & KX852282a & KX852284a \\
\hline P. himalayensis & Cui 9620 (BJFC) & China, Tibet & Picea likiangensis & KX673605a & KX852286a \\
\hline P. himalayensis & Cui 9320 (BJFC) & China, Tibet & Picea likiangensis & JQ772471 & JQ772477 \\
\hline P. himalayensis & Cui 9618 (BJFC) & China, Tibet & Picea likiangensis & KX673604a & KX852285a \\
\hline P. laricis & Dai 15862 (BJFC) & China, Xinjiang & Larix sp. & KY000005a & KY000010a \\
\hline P. laricis & TFC 1981-38 & $\begin{array}{l}\text { Russia, Primorsk } \\
\text { Territory }\end{array}$ & Picea sp. & FJ775559 & FJ775585 \\
\hline P. laricis & PRM 892094 & France, Pelvoux & Larix decidua & FJ775567 & FJ775587 \\
\hline P. pini & BRNM 737548 & $\begin{array}{l}\text { Turkey, Isparta } \\
\text { Province }\end{array}$ & Pinus sp. & JQ772470 & JQ772476 \\
\hline P. pini & BRNM 712792 & $\begin{array}{l}\text { Croatia, Isle of } \\
\text { Korčula }\end{array}$ & Pinus halepensis & FJ775554 & FJ775599 \\
\hline P. pini & MT 11/13 & Sweden & Pinus sylvestris & KY000008a & KY000012a \\
\hline P. yamanoi & Dai 14795 (BJFC) & $\begin{array}{l}\text { China, Jilin } \\
\text { Province }\end{array}$ & Picea jezoensis & KX673607a & KX852287a \\
\hline P. yamanoi & TFC 1971-24 & $\begin{array}{l}\text { Russia, Sakhalin } \\
\text { Island }\end{array}$ & Picea jezoensis & FJ775551 & FJ775592 \\
\hline P. yamanoi & Dai 8202 (BJFC) & $\begin{array}{l}\text { China, Jilin } \\
\text { Province }\end{array}$ & Picea jezoensis & JQ772469 & JQ772475 \\
\hline P. sp. 1 & Miettinen 10543 & $\begin{array}{l}\text { China, Jilin } \\
\text { Province }\end{array}$ & Pinus koraiensis & KM011978a & KY024313a \\
\hline P. sp. 1 & Spirin 3918 & $\begin{array}{l}\text { Russia, } \\
\text { Khabarovsk Reg }\end{array}$ & Larix gmelinii & KM011979a & KY024314a \\
\hline P. sp. 2 & Spirin 5568-1 & $\begin{array}{l}\text { Russia, } \\
\text { Khabarovsk Reg }\end{array}$ & Pinus pumila & KM011968a & KY024315a \\
\hline P. sp. 2 & Spirin 5567 & $\begin{array}{l}\text { Russia, } \\
\text { Khabarovsk Reg }\end{array}$ & Pinus pumila & KM011967a & KY024316a \\
\hline P. sp. 3 & Korhonen 1136 & $\begin{array}{l}\text { India, Himachal } \\
\text { Pradesh }\end{array}$ & Cedrus deodara & KM011966a & - \\
\hline Onnia leporina & BRNM 712782 & Czech, Jihlava & Picea abies & FJ775542 & FJ775573 \\
\hline
\end{tabular}

\section{Phylogenetic analyses}

Sequences were aligned in BioEdit with ClustalX and edited manually as necessary (Hall 1999). The resulting alignment was used in phylogenetic analyses with Maximum parsimony (MP) 
and Bayesian inference (BI). The sequences of Onnia leporina (Fr.) H. Jahn were chosen as the outgroup following Tomšovský \& Kout (2013).

For MP analysis, the tests were implemented in PAUP* 4.0b10 using 1000 random sequence additions during the heuristic search, and all characters of the sequences were equally weighted and gaps were treated as missing data. Max-trees were set to 5000 branches of zero length were collapsed, and all parsimonious trees were saved. Branch supports was assessed using a bootstrap (BT) analysis by performing 1000 replicates datasets with random sequences addition for each bootstrap replicate (Felsenstein 1985). Descriptive tree statistics, tree length (TL), consistency index $(\mathrm{CI})$, retention index (RI), rescaled consistency index (RC), and homoplasy index (HI), were calculated for each tree generated.

The best-fit evolution model was determined by MrMODELTEST2.3 (Nylander 2004, Posada \& Crandall 1998) for BI. Four Markov chains were run for two independent runs from random starting trees with 4,000,000 generations, keeping one tree every 1,000 generation. The first one-fourth generations were discarded as burn-in. A majority rule consensus tree of all remaining trees was calculated.

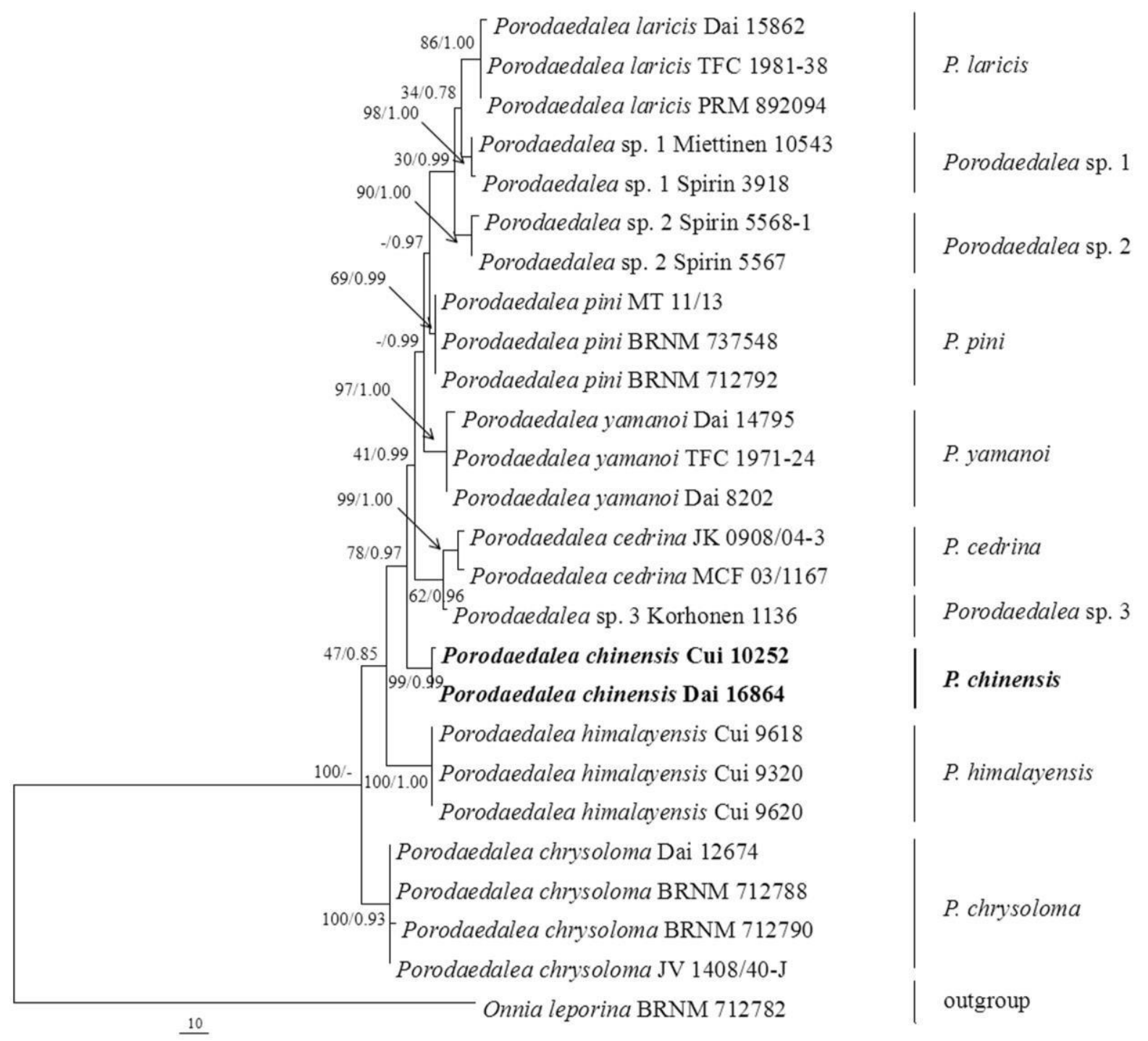

Figure 1 - Phylogenetic position of Porodaedalea chinensis inferred from the combined two genes (ITS and tefl- $\alpha$ ).

\section{Results Molecular phylogeny}

The combined dataset had an aligned length of 1843 characters, of which 1496 were constant, 261 were variable and parsimony-uninformative, and 86 were parsimony-informative. MP analysis 
yielded four equally parsimonious trees $(\mathrm{TL}=413, \mathrm{CI}=0.889, \mathrm{HI}=0.111, \mathrm{RI}=0.846, \mathrm{RC}=$ 0.751). The Bayesian analysis was performed using the GTR $+\mathrm{I}+\mathrm{G}$ model for the ITS and tefl- $\alpha$ dataset. BI result is similar topology with MP, and only the MP tree is shown with both BT and BPPs values at the nodes (Fig. 1). Porodaedalea chinensis formed a distinct lineage and clustered within Porodaedalea clade with a strong support $(\mathrm{BT}=99 \%, \mathrm{BPP}=0.99)$. The new species is closely related $P$. yamanoi, $P$. cedrina and $P$. pini with a low support $(\mathrm{BT}=78 \%$, BPP $=0.97)$. In addition, Porodaedalea sp. $1(\mathrm{BT}=98 \%, \mathrm{BPP}=1.00)$ form Jilin Province of China and the Russia Far East, Porodaedalea sp. $2(\mathrm{BT}=90 \%$, BPP $=1.00)$ from Khabarovsk of Russia and Porodaedalea sp. $3(\mathrm{BT}=62 \%$, BPP $=0.96)$ from India also formed three distinct lineages, and they most probably are undescribed species.

\section{Taxonomy}

Porodaedalea chinensis S.J. Dai \& F. Wu, sp. nov.

Figs $2-3$

Index Fungorum number: IF 553333; Facesoffungi number: FoF 02918

Etymology - chinensis $=$ refers to the locality in China.

Fruiting body - Basidiocarps perennial, pileate, solitary to clusters, without odour or taste, hard corky when fresh, heavy and woody hard when dry. Pilei projecting up to $4.8 \mathrm{~cm}, 10 \mathrm{~cm}$ wide and $1.1 \mathrm{~cm}$ thick at base. Pileal surface greyish brown to black, concentrically sulcate with narrow zones, irregularly cracked and become encrusted with age; margin obtuse. Pore surface cinnamon to yellowish brown when fresh, becoming honey-yellow to rust-brown and slightly glancing when dry. Pores circular to angular, 2-3 per mm; dissepiments thick, entire. Context cinnamon, woody hard, up to $0.5 \mathrm{~mm}$ thick. Tubes yellowish brown, woody hard, up to $0.6 \mathrm{~cm}$ long.

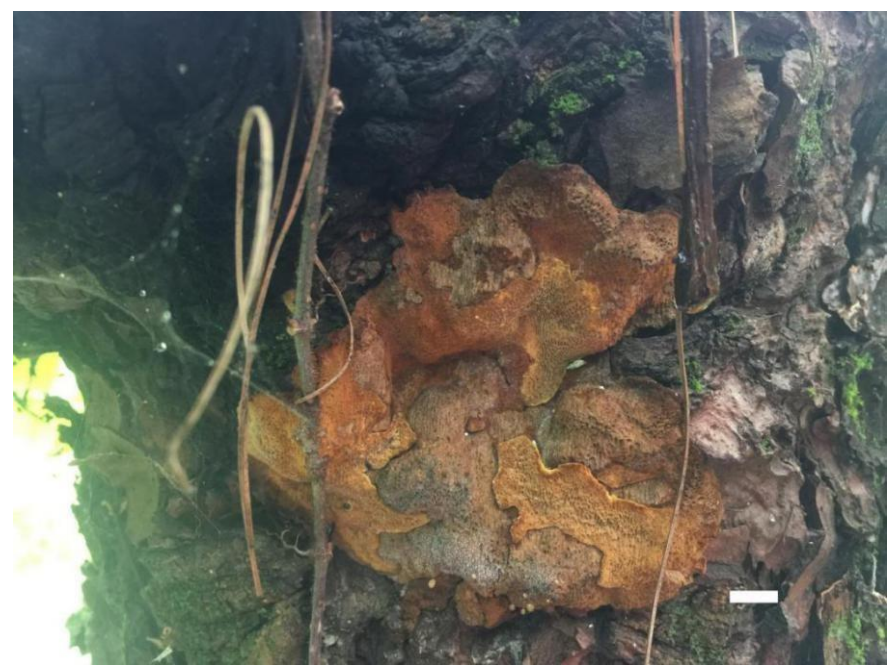

Figure 2 - Basidiocarps of Porodaedalea chinensis (paratype, Dai 16864). Scale bar $=1 \mathrm{~cm}$.

Hyphal structure - Hyphal system dimitic; generative hyphae simple septate; tissue darkening but unchanged in $\mathrm{KOH}$.

Context - Generative hyphae hyaline, thin-walled, occasionally branched, frequently simple septate, 1.5-3 $\mu \mathrm{m}$ in diam; skeletal hyphae dominant, yellowish brown, thick-walled with a wide lumen, rarely branched, occasionally septate, straight, regularly arranged, $3-5 \mu \mathrm{m}$ in diam.

Tubes - Generative hyphae frequent, hyaline, thin-walled, occasionally branched, frequently septate, some bearing crystals at dissepimental edges, 1-2 $\mu \mathrm{m}$ in diam; skeletal hyphae yellowish brown, thick-walled with a narrow to wide lumen, unbranched, occasionally septate, straight, parallel along the tubes, $2-5 \mu \mathrm{m}$ in diam. Setae frequent, mostly originating from subhymenim, sometimes embedded in trama, but not seen at dissepimental edges, subulate, dark brown, thickwalled, (33-)35-69(-74) $\times 5-14(-15) \mu \mathrm{m}$; cystidioles infrequent, clavate, hyaline, thin- 
walled; basidia clavate, bearing four sterigmata and a simple septum at the base, $11-20 \times 4-7 \mu \mathrm{m}$; basidioles dominating in hymenium, pear-shaped to capitate, mostly shorter than basidia.

Spores - Basidiospores broadly ellipsoid, hyaline, thin- to slightly thick-walled, smooth, without guttule, usually glued in tetrads, IKI-, moderately $\mathrm{CB}+,(3.9-) 4-6 \times 3-4.8 \mu \mathrm{m}, \mathrm{L}=4.95$ $\mu \mathrm{m}, \mathrm{W}=4.00 \mu \mathrm{m}, \mathrm{Q}=1.19-1.27(\mathrm{n}=60 / 2)$.

Known distribution - Yunnan Province, China.

Material examined - China, Yunnan Province, Chuxiong, Zixishan Forest Park, on living tree of Pinus yunnanensis, 16 April 2011, Cui 10252 (BJFC011148, holotype). China, Yunnan Province, Xishan Forest Park, on living tree of Pinus yunnanensis, 2 April 2016, Dai 16864 (BJFC011148, paratype); Chuxiong, Zixishan Forest Park, on living tree of Pinus yunnanensis, 16 April 2011, Cui 10254 (BJFC011149, paratype).
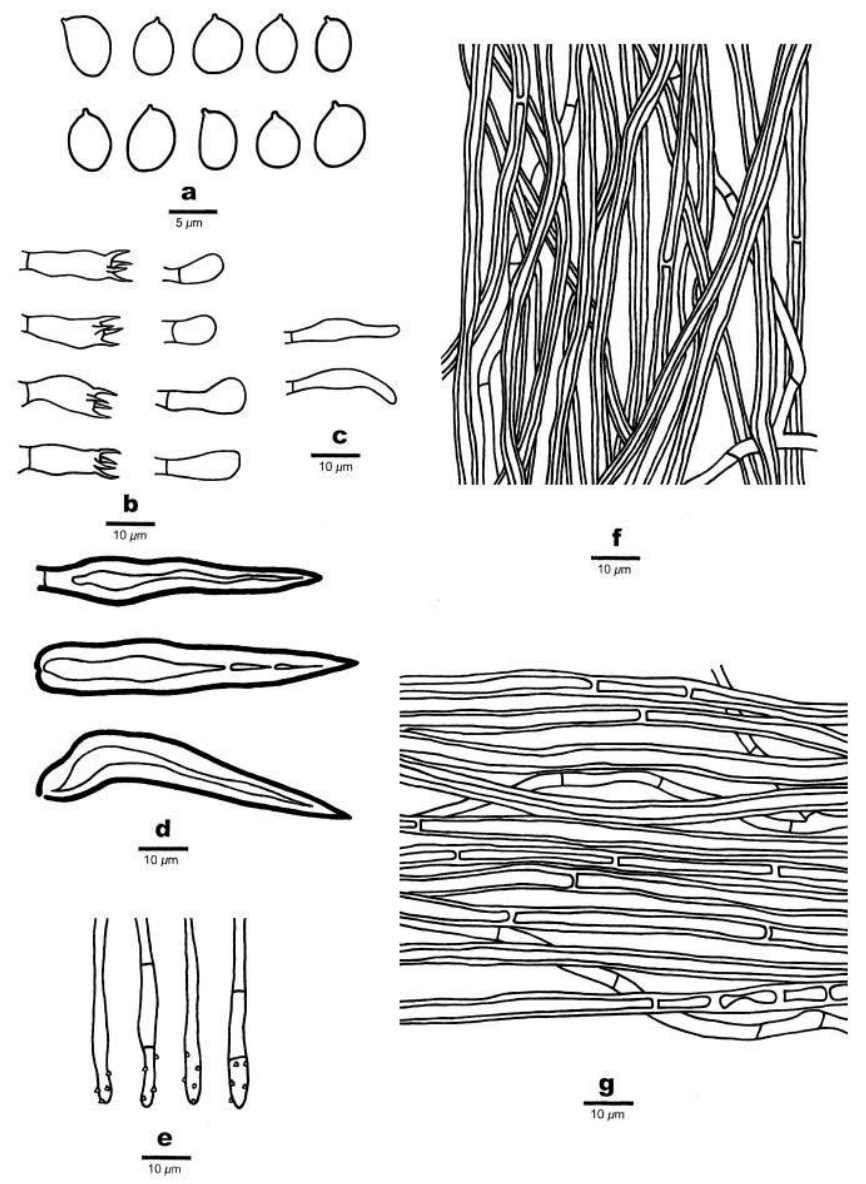

Figure 3 - Microscopic structures of Porodaedalea chinensis (holotype). a Basidiospores. b Basidia and basidioles. c Cystidioles. d Setae. e Hyphae at dissepimental edge. f Hyphae from trama. g Hyphae from context.

\section{Discussion}

Although Porodaedalea was established by Murrill in 1905, it was previously treated as the Phellinus pini complex (Gilbertson \& Ryvarden 1987, Ryvarden \& Melo 2014). The molecular analyses showed it was different from other groups in the Phellinus sensu lato and accepted as an independent genus (Wagner \& Fischer 2002). Tomšovský \& Kout (2013) employed the ITS and tefl- $\alpha$ to study Porodaedalea group that produced six strongly supported terminal clades. Our results confirmed that $P$. chinensis formed a distinct lineage from the analyses of ITS and tefl- $\alpha$ DNA sequences. $P$. chinensis was grouped with $P$. pini, $P$. cedrina and $P$. yamanoi in our phylogeny (Fig. 1). However, $P$. pini differs from $P$. chinensis in having wider hymenial setae (8$15 \mu \mathrm{m})$ and usually larger basidiospores (5.3-6.2 $\times 4-5.5 \mu \mathrm{m}$, Table 2). In addition, $P$. pini has 
slightly larger pores (1-3 per mm, Table 2). Compared with $P$. chinensis, $P$. cedrina also has bigger basidiospores $(5-6 \times 4.0-5.1 \mu \mathrm{m})$ and wider setae $(6-18 \mu \mathrm{m}$, Tomšovský \& Kout 2013). Moreover, it grows exclusively on Cedrus and has a distribution in Mediterranean area (Tomšovský \& Kout 2013). P. yamanoi is different from $P$. chinensis in having interwoven tramal hyphae, and usually growing on Picea jezoensis (Dai 2010).

In fact, Porodaedalea chinensis is more similar to $P$. laricis in macromorphology, but $P$. laricis has shorter setae $(30-58 \times 6-12 \mu \mathrm{m})$ and slightly bigger basidiospores $(4.9-5.5 \times 3.5-4.2$ $\mu \mathrm{m}$, Table 2). The distribution of $P$. chinensis and $P$. himalayensis is overlap, but the latter species has smaller pores (5-7 per $\mathrm{mm})$, shorter setae $(27-39 \mu \mathrm{m})$, distinctly ovoid basidiospores, and grows mostly on Picea (Dai 2010).

Table 2 A comparison of morphological and ecological characters of Porodaedalea species.

\begin{tabular}{|c|c|c|c|c|}
\hline Species & $\begin{array}{l}\text { Distribution/ } \\
\text { substrate }\end{array}$ & $\begin{array}{l}\text { Pores } \\
\text { (per mm) }\end{array}$ & Setae $(\mu \mathrm{m})$ & Basidiospores $(\mu \mathrm{m})$ \\
\hline P. chrysoloma & Europe; Picea & $2-3$ & $\begin{array}{l}30-55 \times 6-11 \\
\mathrm{~L}=41.9, \mathrm{~W}=8.1\end{array}$ & $\begin{array}{l}4-5.3 \times 3-4.5 \\
\mathrm{~L}=5, \mathrm{~W}=4.1, \mathrm{Q}=1.24\end{array}$ \\
\hline P. chinensis & East Asia; Pinus & $2-3$ & $\begin{array}{l}35-69 \times 5-14 \\
\mathrm{~L}=52.9, \mathrm{~W}=9.1\end{array}$ & $\begin{array}{l}4-6 \times 3-4.8 \\
\mathrm{~L}=4.9, \mathrm{~W}=4, \mathrm{Q}=1.19-1.27\end{array}$ \\
\hline P. himalayensis & East Asia; Picea & $5-6$ & $\begin{array}{l}24-43 \times 6-10 \\
\mathrm{~L}=33.4, \mathrm{~W}=7.9\end{array}$ & $\begin{array}{l}4.3-5.8 \times 3.5-4.8 \\
\mathrm{~L}=4.8, \mathrm{~W}=4, \mathrm{Q}=1.21\end{array}$ \\
\hline P. laricis & East Asia; Larix & $2-3$ & $\begin{array}{l}30-58 \times 6-12 \\
\mathrm{~L}=44.5, \mathrm{~W}=8.3\end{array}$ & $\begin{array}{l}4.9-5.5 \times 3.5-4.2 \\
L=5, W=3.9, Q=1.27\end{array}$ \\
\hline P. pini & Europe; Pinus & $1-3$ & $\begin{array}{l}39-67 \times 8-15 \\
\mathrm{~L}=50.8, \mathrm{~W}=10.6\end{array}$ & $\begin{array}{l}5.3-6.2 \times 4-5.5 \\
\mathrm{~L}=5.9, \mathrm{~W}=4.9, \mathrm{Q}=1.2\end{array}$ \\
\hline P. yamanoi & East Asia; Picea & $3-4$ & $\begin{array}{l}36-65 \times 7-13 \\
\mathrm{~L}=47.5, \mathrm{~W}=10\end{array}$ & $\begin{array}{l}4.2-5.8 \times 3.8-4.5 \\
\mathrm{~L}=4.9, \mathrm{~W}=4.1, \mathrm{Q}=1.19\end{array}$ \\
\hline
\end{tabular}

\section{Acknowledgements}

We express our gratitude to Prof. Yu-Cheng Dai (BJFC, China) for allowing us to study his specimens. The research was supported by the Fundamental Research Funds for the Central Universities (Project Nos. 2016ZCQ04). The research of J. Vlasák was funded by institutional support RVO: 60077344.

\section{References}

Brazee NJ, Lindner DL. 2013 - Unravelling the Phellinus pini s.l. complex in North America: a multilocus phylogeny and differentiation analysis of Porodaedalea. Forest Pathology 42, 132-143.

Dai YC. 2010 - Hymenochochaetaceae (Basidiomycota) in China. Fungal Diversity 45, 131-343.

Felsenstein J. 1985 - Confidence intervals on phylogenetics: an approach using bootstrap. Evolution 39, 783-791.

Fiasson JL, Niemelä T. 1984 - The Hymenochaetales: a revision of the European poroid taxa. Karstenia 24, 14-28.

Fischer M. 1994 - Pairing tests in the Phellinus pini group. Mycologia 86, 524-539.

Fischer M. 1996 - Molecular and microscopical studies in the Phellinus pini group. Mycologia 88, 230-238.

Fischer M. 2000 - Porodaedalea (Phellinus pini group, Basidiomycetes) in Europe: a new species on Larix sibirica, P. niemelaei. Karstenia 40, 43-48.

Gilbertson RL, Ryvarden L. 1987 - North America polypores 2. Fungiflora, Oslo, 549-622.

Hall TA. 1999 - BioEdit: a user-friendly biological sequence alignment editor and analysis program for Windows 95/98/NT. Nucleic Acids Symposium Series 41, 95-98. 
He SH, Li HJ. 2011 - Hymenochaete rhododendricola and H. quercicola spp. nov. (Basidiomycota, Hymenochaetales) from Tibet, southwestern China. Nordic Journal of Botany 29, 484-487.

Larsen MJ, Melo IM. 1996 - Neotypification of Phellinus pini. Mycologia 88, 839-843.

Larsen MJ, Stenlid J. 1999 - Neotypification of Phellinus chrysoloma. Folia Cryptogam Estonica 34, 9-13.

Larsen MJ. 2000 - Phellinus gilbertsonii sp. nov. from western North America causing heart-rot of coastal Douglas-fir. Folia Cryptogam Estonica 37, 51-54.

Murrill WA. 1905 - The Polyporaceae of North America 11. A synopsis of the brown pileate species. Bulletin of the Torrey Botanical Club 32, 353-371.

Niemelä T, Kinnunen J, Larsson KH, Schigel DS, Larsson E. 2005 - Genus revisions and new combination of some North European polypores. Karstenia 45, 75-80.

Niemelä T. 1985 - Mycoflora of Poste-de-la-Baleine, northern Quebec: polypores and the Hymenochaetales. Naturaliste Canadh 112, 445-472.

Nylander JAA. 2004 - MrModeltest v2. Program distributed by the author. Evolutionary Biology Centre, Uppsala University.

Petersen JH. 1996 - Farvekort. The Danish Mycological Society's colour-chart. Foreningen til Svampekundskabens Fremme, Greve 6.

Posada D, Crandall KA. 1998 - Modeltest: testing the model of DNA substitution. Bioinformatics 14, 817-818.

Rehner SA, Buckley E. 2005 - A Beauveria phylogeny inferred from nuclear ITS and EF1-a sequences: evidence for cryptic diversification and links to Cordyceps teleomorphs. Mycologia 97, 84-98.

Ryvarden L, Melo I. 2014 - Poroid fungi of Europe. Synopsis Fungorum 31, 1-455.

Tomšovský M, Kout J. 2013 - Porodaedalea cedrina (Basidiomycota, Agaricomycetes, Hymenochaetales) - a new polypore from the Mediterranean area. Nova Hedwigia 96, 419426.

Tomšovský M, Sedlák P, Jankovský L. 2010 - Species recognition and phylogenetic relationships of European Porodaedalea (Basidiomycota, Hymenochaetales). Mycological Progress 9, 225-233.

Wagner T, Fischer M. 2002 - Proceeding towards a natural classification of the worldwide taxa Phellinus sl and Inonotus sl, and phylogenetic relationships of allied genera. Mycologia 94, 998-1016.

White TJ, Bruns T, Lee S, Taylor J. 1990 - Amplification and direct sequencing of fungal ribosomal RNA genes for phylogenetics. In: Innis MA, Gelfand DH, Sninsky JJ, White TJ (Eds.) PCR Protocols: a guide to methods and applications. Academic Press, San Diego, 315322.

Zhao CL, Cui BK, Song J, Dai YC. 2015 - Fragiliporiaceae, a new family of Polyporales (Basidiomycota). Fungal Diversity 70, 115-126.

Zhou LW, Nakasone KK, Burdsall Jr. HH, Ginns J et al. 2016 - Polypore diversity in North America with an annotated checklist. Mycological Progress 15, 771-790. 